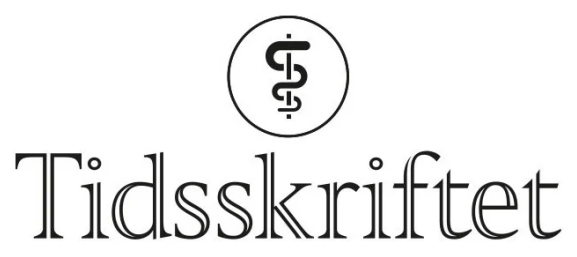

DEN NORSKE LEGEFORENING

\title{
I spennet mellom Gud og Darwin
}

PERSONLIGE OPPLEVELSER

\section{KNUT HAAKENAASEN}

knhaaken@gmail.com

Knut Haakenaasen er spesialist i psykiatri, tidligere overlege ved DPS Groruddalen og pensjonist fra 2018.

\section{Dette er en erindring fra den gamle Anatomen anno 1968.}

Prosektor Hansen snubler av gårde på uryddig sørlandsdialekt. Han er en tynnhåret kar i 40-åra, alltid med en grå hinne av flass på den hvite frakkekragen. Ansiktet er uttrykksløst og blikket flyter ut bak tykke hornbriller. Med jevne mellomrom stopper han midt i taleflommen, klør seg i hodet og myser mot taket, som om han påkaller høyere makter for å komme videre. Så snurper han munnen, er kanskje blitt bønnhørt, for en ny ordflom følger uten unødige kunstpauser. Men heller ikke denne gangen kommer han til poenget før han på ny må trekke pusten og tilkalle hjelp fra det høye. Han minner om en lekpredikant fra Sarons dal, oppfostret på tungetale og Den hellige ånd, men uten de karismatiske nådegaver som kjennetegner en virkelig sjelefanger. Kanskje er det derfor han har viet seg til det darwinistiske kall i hovedstaden, der han denne formiddagen i begynnelsen av september gjør sitt ytterste for å fange studentenes interesse for Myxine glutinosa, den eiendommelige slimålen, som er dagens tema i kurset i komparativ anatomi.

Hver student har et eksemplar av arten foran seg på pulten, fiksert til underlaget med knappenåler, slik at studentene kan dissekere seg nedover denne meget tidlige forløperen for menneskeslekten i det tempoet som Hansen doserer.

Prosektor Hansen snubler i ordene, i nesten religiøs hengivelse, som om det er selveste skapelsesberetningen han bretter ut for dem. Når alt kommer til alt, er det kanskje ikke så langt mellom Darwin og Bibelen, funderer jeg, mens jeg bretter ut ålens brystparti, der det rudimentære hjertet åpenbarer seg. Mens Gud klarte seg med en uke på skapelsen, trengte Darwin en milliard år på samme prosjekt. Under evighetens synsvinkel er kanskje ikke avstanden så stor likevel, for prosektor Hansen er minst like ivrig i sitt naturvitenskapelige kall som sine mer gudløse kolleger. Ja, det var som om han hadde et budskap å komme med, et budskap om livets mysterium, om den skapende hånd som lå bak alle anatomiske detaljer.

«Han minner om en lekpredikant fra Sarons dal, men uten de karismatiske nådegaver som kjennetegner en virkelig sjelefanger» 
Og gradvis, mens prosektor Hansen doserer seg gjennom ontogenesens mysterium, går det opp for meg at det er en slags forbindelse mellom kristendom og medisin. Legene var en opphøyd gruppe i samfunnet, et slags frimurerlaug, et moderne presteskap. Den store hvite flokk. De var opplært til å se på legegjerningen som et kall. Selv i det marxistiske året 1968 utgjorde de kristne på kullet en ikke uanselig gruppe, og den kristne medisinerforeningen var den største på Universitetet, nest etter teologi.

Mens prosektor Hansen tegner og forteller, strever jeg med å få opp entusiasmen for det formalinstinkende dyret foran meg. Et tidlig virveldyr, doserer han. Legg merke til differensieringen av mesoderm, endoderm og ektoderm. Omtrent som hos et tre måneder gammelt menneskefoster! Dermed mener han å fastslå selve beviset for at artenes utvikling på jorden, ontogenesen, avspeiles i menneskets utvikling fra unnfangelse til fødsel, den såkalte fylogenesen. I løpet av ni måneder gjennomgår mennesket en biologisk metamorfose som gjenspeiler biologiens utvikling på jorden gjennom en milliard år, jubler han. Det er sannelig et mirakel, dere!

\section{«Gradvis, mens prosektor Hansen doserer seg gjennom ontogenesens mysterium, går det opp for meg at det er en slags forbindelse mellom kristendom og medisin»}

Jeg sitter nederst ved vindusrekka og har godt utsyn over kurssalen. 7o studenter sitter benket langs fire parallelle langbord og jakter på sin egen opprinnelse. Prosektor Hansens framtoning bader i skarpt sidelys fra vinduene, et lys som gir ham en nesten profetisk utstråling. Han ser forventningsfullt på sine disipler, men ingen av dem får anfektelser over det oppsiktsvekkende budskapet. Noen går riktignok løs på slimålen med en målbevissthet som om de skal innta et bedre måltid, men de fleste studerer sitt objekt med nøktern distanse, eller endog med en viss motvilje. Her er det rasjonaliteten som rår grunnen mens undringen har gått i kloster. Etter to uker på medisin begynner vi allerede å tenke som ekte skolemedisinere, fastslår jeg.

Det går mot slutten av dagens diskurs, og prosektor Hansen må fastslå at interessen for skaperverket er heller laber blant dagens unge medisinere. Studentene stiller seg i kø foran utslagskummene bakerst i lokalet, der redskapene rengjøres og hendene vaskes. 70 stykk maltrakterte slimåler havner i hvite plastbøtter, hvorfra de snart ekspederes til de evige jaktmarker via instituttets forbrenningsovn. Senere skal et tilsvarende antall frosker gå samme vei, etterfulgt av stadig mer høytstående dyr, i hvert fall mus og rotter, før studentene allerede neste semester ender opp med kronen på skaperverket, selve mennesket. Jeg har hørt rykter om hva som foregår der oppe i det aller helligste, på disseksjonssalen, der himmelsk lys sildrer ned gjennom blakkede takvinduer. Der ligger de på rekke og rad, de avsjelede legemer som har donert kroppen i vitenskapens tjeneste.

Men foreløpig dreier det seg altså om Myxine glutinosa, og jeg er fortsatt lykkelig uvitende om hva som senere skal vederfares oss. For i det Herrens år 1968 er medisinstudiet fortsatt så viselig innrettet at man bare gradvis nærmer seg sakens kjerne, lidelsens mysterium, slik at man skal få rikelig tid til å bygge opp en rasjonell rustning mot livets endelige sannheter. Den formaliserte omgangen med formalinfikserte lik blir en slags vaksine mot den naturlige følsomhet, som pent og pyntelig kan avgå ved døden før man starter opp den kliniske delen av studiet.

Men enn så lenge er vi noviser i legekunsten og naivt forventningsfulle til møtet med de levende pasientene et par år fram i tid, når det virkelige studiet tar til.

Hansen er et pseudonym.

Publisert: 13. desember 2021. Tidsskr Nor Legeforen. DOI:10.4045/tidsskr.21.0579

C Tidsskrift for Den norske legeforening 2023. Lastet ned fra tidsskriftet.no 26. april 2023. 